\title{
Statyba
}

\section{THE DEVELOPMENT OF INNOVATION ACTIVITIES IN BUILDING CONSTRUCTION BY SAVING HEATING RESOURCES}

\section{B. Melnikas , A. Jakubavičius MSc \& R. Strazdas MSc}

To cite this article: B. Melnikas , A. Jakubavičius MSc \& R. Strazdas MSc (1998) THE DEVELOPMENT OF INNOVATION ACTIVITIES IN BUILDING CONSTRUCTION BY SAVING HEATING RESOURCES, Statyba, 4:3, 235-242, DOI: 10.1080/13921525.1998.10531410

To link to this article: https://doi.org/10.1080/13921525.1998.10531410

Published online: 26 Jul 2012.

Submit your article to this journal $\llbracket$

Џ Article views: 49 


\title{
THE DEVELOPMENT OF INNOVATION ACTIVITIES IN BULDING CONSTRUCTION BY SAVING HEATING RESOURCES
}

\author{
B. Melnikas, A. Jakubavičius, R. Strazdas
}

\section{Introduction}

Importance of the problem. Building is one of the important branches of economy that predetermines to a great extent the economic, social and technological development of the country.

The quantity and quality of products created in construction and their economic parameters influence largely the possibilities to achieve a certain level of social life and of modern material production and services: building construction products are an essential factor effecting the level of costs in all spheres of public economic life.

The development of building sector is directly related to the possibilities to effectively use and save heating resources.

Construction plays an especially important role in the present period of economic development in Lithuania. This is related to the following circumstances.

- the major part of buildings and structures existing in Lithuania as to their level of quality are not adequate to the modern conditions (of special mention should be the inadequacy of the requirements that are related to the use and saving of energy resources): modernization of buildings and structures and their adaptation to modern requirements are directly related to the increasing volumes of building work (including repairing), understanding that these works must be oriented towards the provision of a new quality (as a matter of fact, modernization and adaptation of buildings and structures to the modern requirements first of all concern heat saving);

- construction of new modern buildings and structures has been increasing and should increase in the future still more, its growth is predetermined by gradual distribution and implementation of new social lifestyle standards and new standards in the sphere of production and services; the distribution and implementation of new norms and standards is related to the processes of Lithuania's integration into the European Union and global markets;

- the growth of building in Lithuania is closely linked with the development of innovations; it is of special importance for construction enterprises, the compatibility of which under a free market conditions is predetermined primarily by their ability to integrate into the formation and spreading of innovations: every enterprise must act as the generator, propagator, successor of innovations (most building enterprises must manifest themselves as generators of innovations namely in the sphere of heat saving).

The efforts to develop the innovation activities in building enterprises predetermine the necessity to solve a number of theoretical and practical problems; in this respect the following should be distinguished:

- specification of such trends in building the development of which requires essential innovations;

- identification of such organizational forms, on the basis of which the development of innovation activities in building would be especially effective;

- targeting of possibilities for the development of innovation activities on the basis of the development of consultancy services.

The specified problems require to carry out a number of studies, including saving the heating resources. Material and results of such research are given in detail.

The objective of research. Searching for ways to develop the innovation activities in building, including the sphere of saving the heat resources, it is necessary 
to develop a special system of institutions directly involved in performing the innovation activities, oriented to the work under market conditions and able to implement effective technologies for the use of heat, other measures for heat saving. The formation of such system requires the creation of appropriate managerial-organizational models and the evaluation of the possibilities of their implementation.

Thus the formation of the system of institutions involved in the innovation activities and the evaluation of the possibilities of its organization is perceived as an objective of study devoted to the problems of innovation activities in building.

This goal requires the solution of the following tasks:

- identification of the innovation priorities as the subject of study;

- formation of the innovation activity organizational model;

- evaluation of the possibilities for the integration of consultancy activities into the innovation process.

Methods of research. The striving to achieve the goal specified is related to the application of various methods of research. Among these, the following should be distinguished:

- analysis of the tendencies in Lithuanian social and economic development and its modernization;

- comparative analysis, oriented to evaluating the efficiency of various types of innovation activity organization models.

\section{Research Results}

Innovation priorities as the object of research. At present there are over 10,000 enterprises in Lithuania that are involved in building or related activities. Small and medium scale enterprises prevail among them: their characteristic feature is that up to 50 workers constantly work in each of them, and the income per year from building and repairing works performed constitute approximately from 0.5 to 2-3 million Litas.

Certain priorities are characteristic of these enterprises, expressing both the general problems of innovations in building and specific problems, which could also embrace topical issues of innovations connected with heat saving
Among priorities of the need for innovations in the general case the following may be mentioned:

1. The need for management innovations that are predetermined due to:

- in many enterprises analytic work, oriented to prospective market research, formation of the concepts for developing enterprises and strategic planning, is not organized and constantly performed;

- no clear distribution of functions exists, delegation and powers of some managers are defined in a very stream-lined manner, certain rather important innovation management and administration functions are not in general attributed to the members of the managerial team;

- many management functions, including the implementation of innovations, in fact are attributed to the first manager who is unable in reality to embrace rather extensive range of management and administration problems; as a result of centralization of managerial functions at the level of the first manager, many important issues are not solved or solved in a delayed and not constructive manner;

- structures and units which would focus on the work concerning scientific and technical progress as well as quality management do not function in fact;

- many issues are solved without serious legal, information and management preparation;

- some enterprises lack comprehensive accounting system which could be formed on the basis of the standards applied in the Western countries; for that reason accounting frequently is not precise.

2. Production-technological innovation needs that are predetermined due to:

- labour organization often does not comply and even contradict to the technological process logic;

- outdated methods are often used in building: as a result, the production process is not properly prepared, the usage of time and material is ineffective, no necessary level of quality is ensured;

- no long-term technical development, technological and production improvement concept exists at the enterprises.

3. The needs for economic (especially financial activities) innovations that are predetermined due to the fact that funds intended for investments are not used effectively.

4. The needs for innovations concerning personnel that are predetermined due to: 
- heads of enterprises in terms of their qualifications very often are unable to adopt and implement constructive decisions, which could stabilize the situation at the enterprise and ensure its effective functioning in the future;

- personnel education, qualification improvement and certification are not solved in essence, often any concept on this approach does not exist at enterprises;

- the personnel frequently are selected acording to subjective criteria.

The situation with the given features specifies, in essence, the priorities in the area of innovations. The need for the given innovations and the possibilities of their satisfaction are understood as the priority object of research on innovation activities in building.

No doubt, this object also accumulates heat saving problems.

It should also be noted that the development of building innovations in Lithuania under the existing conditions are related to some specific priorities:

1. Priorities, expressing Lithuania's orientation towards the integration into the European Union; they include innovations in the following areas:

- the implementation of European norms and standards at all the stages of a building product (designing, production of building structures and parts, construction works, preparation of the created objects for maintenance). By the way, these norms and standards are directly related to the innovations in saving heating resources;

- the application of information technologies;

- the improvement of the system of the legal provision of building;

- the development of international contacts: one of the priority objectives in the development of such contacts is to ensure the economical efficiency of buildings and structures.

2. Priorities expressing orientation of innovations towards the implementation of new architectural forms and urban decisions related to spreading new social provisions and values; these priorities embrace such areas as:

- spreading unique architectural and urban decisions, expressing the diversity of styles, forms and architectural aesthetics;
- rapid renovation of buildings and structures as well as architectural ensembles and complexes, adapting their qualitative characteristics in terms of new requirements.

3. Priorities expressing building innovations oriented to ecological and economical requirements; these priorities embrace such areas as:

- effective use of energy in the production of building materials and structures as well as in construction works;

- designing and construction of economical buildings and structures in terms of energy;

- use of ecological building materials and structures.

Organizational model of innovation activities. The stimulation of innovation activities in the following directions would be of special importance for an effective solution of the given problems:

1. Creation and extensive application of innovation activity management methods.

2. Quality improvement of the works performed and services rendered on the basis of innovations.

3. Work efficiency increase on the basis of innovations.

4. Work cost reduction on the basis of innovations.

5. Personnel qualification improvement.

6. Distribution of information (information on new machinery, technology, materials, etc).

Due to the insufficiency of the available potential, small and medium scale enterprises prevailing in the entrepreneurship of building cannot carry out effectively the innovation activities which are directed towards the solution of the specified problems. Therefore it would be reasonable for building enterprises to delegate part of their functions and potential, related to the development of innovation activities, on the basis of cooperation to the establishment and maintenance of regional building innovation development centres. The activities of such centres should integrate Lithuania's scientific and financial potential as well as the production potential operating in the sphere of building.

As a matter of fact, the establishment and maintenance of the regional construction innovation development centres should be oriented to the solution of the problems which are related to heat saving. 


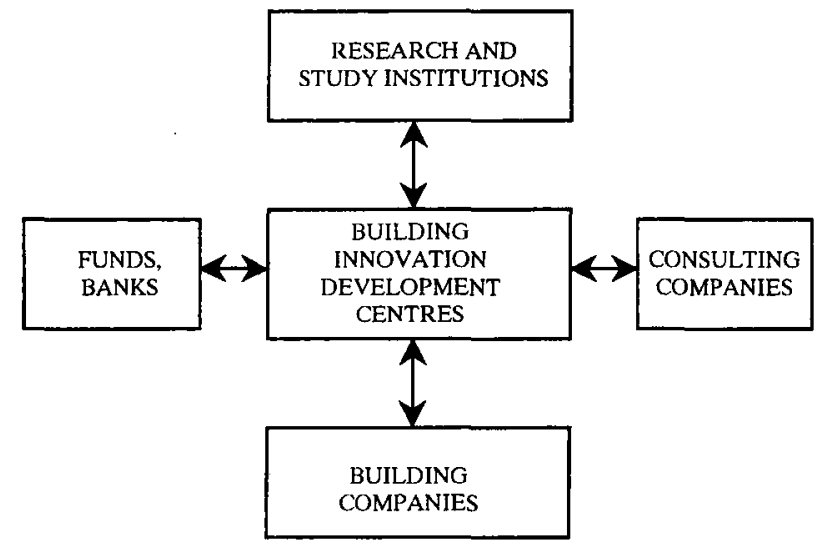

Fig 1. The system of the communication between building innovation development centres (macrolevel)

The building innovation development centres should be the constantly operating units whose basic trends of activity would be:

1. Creation of innovations (research work)

2. Application of innovations

3. Financing of innovations

4. Implementation of innovations

5. Transferring of innovations

6. Personnel training

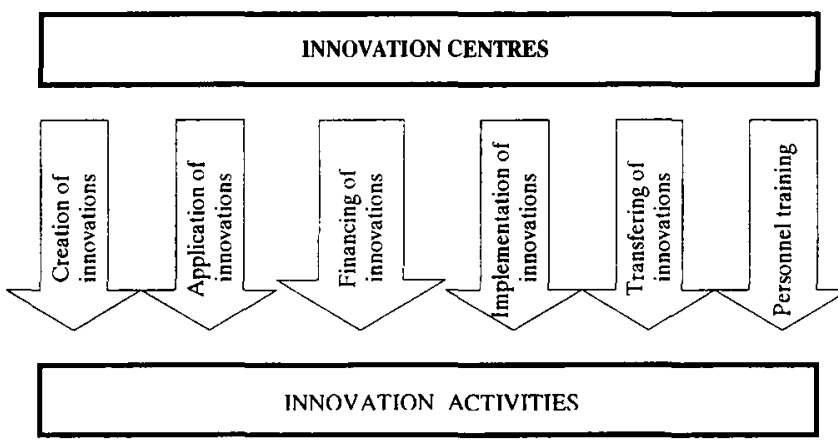

Fig 2. Trends of activities of the building innovation development centres

The following functions should be delegated to the building innovation development centres by building enterprises:

1. At the macroeconomic level:

- Macroeconomic analysis of the building development tendencies

- Building market research, data collection and processing

- Research of the possibilities for the development of entrepreneurship in building

- Research of the possibilities for the development of innovations
2. At the microeconomic level:

- Market research

- Business planning

- Analysis and improvement of organizational structure

- Financial analysis

- Search for partners for innovation activities

- Personnel training

Such centres would make it possible to strengthen relations between research and production.

It has been noticed that currently in Lithuania, unfortunately, there is no such system which would join research and practice in the sphere of building innovations. When forming such a complex system it is necessary to take into account the main principles ensuring its purposefulness, complexity, efficiency, optimality and flexibility.

Purposefulness is understood as the uniformity of the provisions of the formulation and implementation of objectives of the creation and functioning of the system. The main objective is the acceleration of innovation activities, really solving urgent social, economic and technological problems, including those related to heat saving. With the orientation towards this main goal the following tasks should be solved:

- obtaining new knowledge based on fundamental research;

- urgent materialization of fundamental research results (new equipment, technology, labour organization and management forms) in practice.

Complexity is understood as an interrelated use of all technical, organizational, economic and informative relationship of science and production, covering all the stages of the innovation product lifecycle (including fundamental research and product consumption stages and all the participants of innovation activities). Innovation activity organization work must be specified according to the executors, resources and terms of implementation. Complexity must also ensure the continuity of the system, its longevity and rational relations.

Efficiency of the science and production communication system is understood as all-rounded rising of labour efficiency and quality improvement. Final goal of such integration is the rise of production economic efficiency (embracing also problems of heat saving). 
Optimal functionality expresses the efficiency of the system as high as possible. Innovation centres in terms of organizational structures must be such as to ensure close contacts between various links of reseach and practice.

Flexibility of the reseach and production communication system expresses the susceptibility, quick adaptation to new innovation activity conditions, the implementation of the advanced goals and solution of tasks.

The activities of building innovation development centres must be organized by the principle of programming. For example, the personnel for implementation of separate innovation projects should be formed of the personnel of the enterprises concerned, selecting necessary employees, with appropriate skills. This provision directly concerns heat saving.

Cooperation of the organizations concerned should be based on such a scheme: identification of the need - delegation of functions - definition of the objective - formation of the agreement - creation of the work programme - creation and implementation of the self-budgeting mechanism.

The presented innovation activity systematic organizational model would be good for implementing the innovation processes both at macro- and microlevels, including the solution of heat saving problems.

When implementing innovations at a microlevel, an innovation activity organizational model may be transformed and adapted by transferring the functions of the innovation development to consultancy firms.

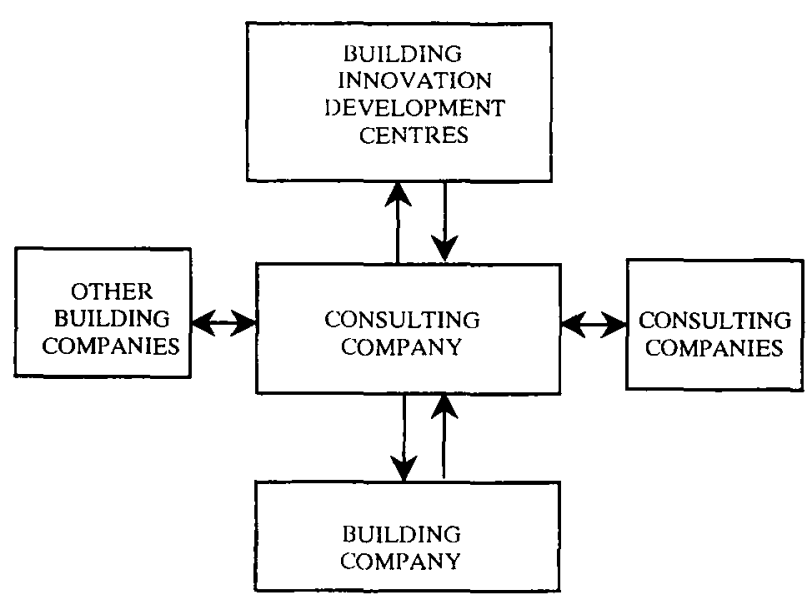

Fig 3. The building innovation development centre communication system (microlevel)
The development of business consultancy as the essential condition to promote the innovation processes. Consultancy activities when promoting innovation processes may be considered in two aspects:

- the importance of consultancy activities in terms of the creation of innovations;

- the importance of consultancy activities in transferring the innovation knowledge.

Research conducted by the European Commission in 1997 in the sphere of creation and implementation of innovations shows that at present the weak link as regards the development of innovations is not the creation of new innovations, but the adaptation of the existing innovations to the entrepreneurship. The heart of the matter is that enterprises in the European Union countries use and implement seldom innovations in their business: many experts in this area agree with such a conclusion made by research. The most vivid example is the statement made by Sean McCarthy, the Chairman of the Board of the Irish National Innovation Programme:

"Currently there is no lack in terms of the results of the research performed. However, to transform academic research to the marketable products may be difficult due to the fact that needs of scientists and businessmen practically are diametrically opposite. Scientists strive to publish their research and gain recognition, and businessmen are concerned with commercial superiority and reliability." [2]

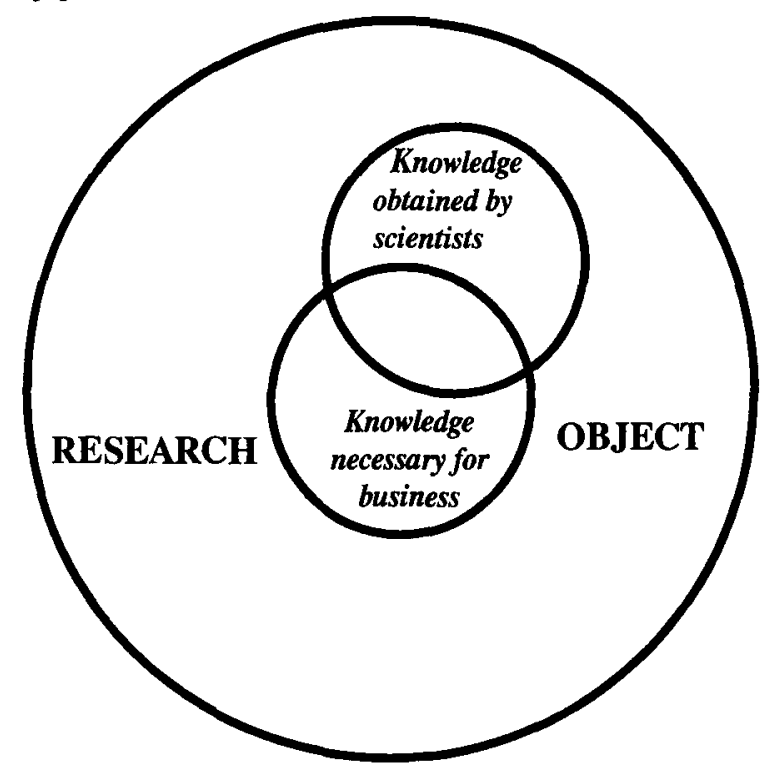

Fig 4. Inadequacy of knowledge obtained by scientists and knowledge necessary to be applied in entrepreneurship 
The inadequacy of knowledge obtained by scientists and knowledge necessary to be applied in entrepreneurship is shown schematically.

Lithuanian building enterprises are faced with problems, related not only to the application of innovation knowledge received by scientists, but also with the problems concerning the adaptation of the already used innovations of building companies of the developed countries to the conditions of Lithuania. To solve these problems additional applied research is necessary that is oriented to a specific enterprise and the situation. Otherwise, the additional knowledge of the object is necessary. The importance of consultants in this process of knowledge is that they perform the following functions:

- define what innovation knowledge received during a research may be applied to a specific building enterprise of Lithuania;

- define what innovations used by building enterprises of other countries may be adapted to the conditions of Lithuania;

- carry out research and receive additional knowledge that innovation knowledge obtained during research and used by building enterprises of other countries could be used at a particular enterprise of Lithuania.

The role of consultancy activities when receiving additional knowledge which are necessary for using an innovation at a specific enterprise is very important. Having in mind that small building enterprises dominate in Lithuania which have no sufficient internal potential for carrying out additional research, the participation of consultants is one of the main conditions for developing the innovation activities in Lithuania. This provision is very urgent especially in heat saving problems.

For the development of the innovation activities in Lithuania, of importance is not only the creation of innovations and their adaptation to the conditions of Lithuania, but also the implementation of the innovations that have already been applied in the developed countries. In most cases, study and educational institutions distinguish themselves as active propagators of building innovations; unfortunately, it is not possible to miss certain narrowness of these institutions in spreading innovations.

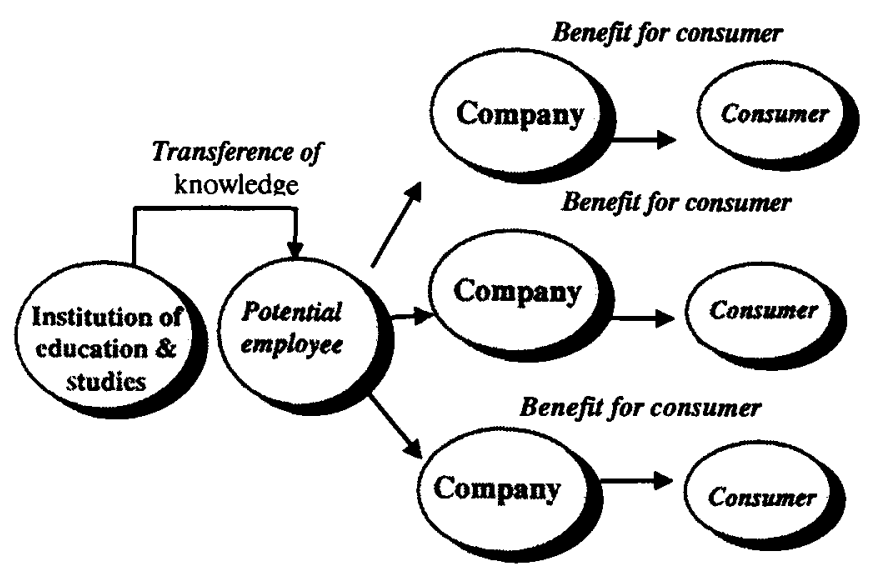

Fig 5. Scheme for transference-spreading of innovations with the participation of study and educational institutions

The narrowness of study and educational institutions when transferring innovation knowledge to construction enterprises manifests itself by the fact that such innovation transference is indirect and lasts long. Quite a long period of time must pass until the building enterprises adopt knowledge provided by scientific institutions and use them. The main causes are:

- future employees, studying or learning at institutions, are not managers of building enterprises so far. Most often they cannot take decisions on important business management issues;

- no feedback from building enterprises to a study and educational institution, therefore innovations can be differently or not fully understood;

- innovation knowledge may be rejected, since educational institutions transfer it without evaluating specific conditions of a certain building enterprise;

- innovation knowledge may be rejected when facing natural oppositions to novelties and the absence of experience in their implementation.

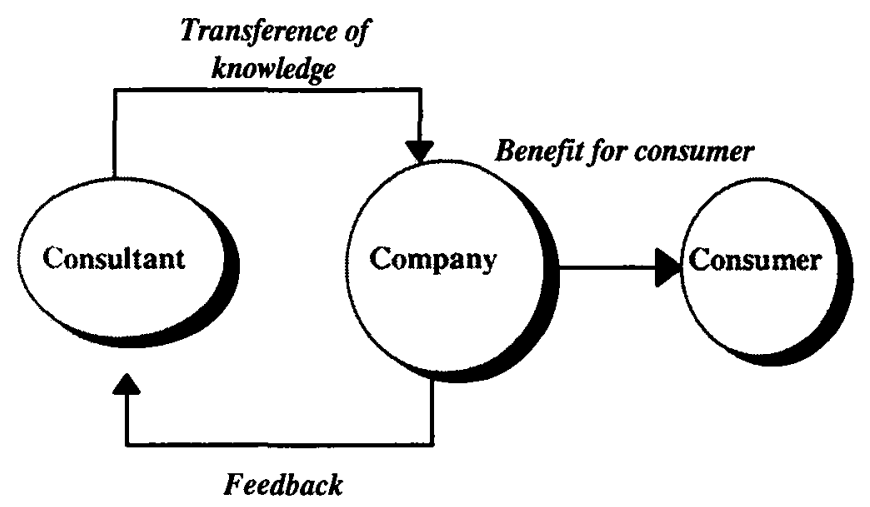

Fig 6. The scheme for transference of innovations using consultants 
The consultant transfers innovations spontaneously to the enterprise, directly contacting the managers of the enterprise, constantly receiving feedback. In addition, the consultant most frequently is the specialist for implementing innovations, who assists in the practical implementation of the transferred innovations.

Advantages of the consultancy process in transferring innovations to construction enterprises are as follows:

- innovations are transferred directly to the managers of a building enterprise;

- the innovations transferred are adopted by a specific construction enterprise, and not by a building enterprise in general, therefore they are more attractive and more easily accepted;

- innovation knowledge are transferred together with the implementation mechanisms, therefore they are more rapidly implemented and not rejected at the stage of implementation;

- there is a feedback which makes it possible to observe and correct the implementation of innovations, taking into consideration the situation formed.

At present an obstacle is observed in Lithuania which does not allow to use actively consultants for implementing the innovations in the building sphere, namely a conditionally high price for consultancy services. One of the main ways of reducing prices for consultancy is the establishment of the network of specialized building innovation centres. By the way, a very prospective trend of specialization is heat saving in building.

\section{Conclusions}

The development of innovation activities in the sphere of building is an important condition for further economic, social, and technological development of the country, therefore the promotion of innovations is considered as a priority problem of building management improvement. Promotion of innovations is especially important as regards heat saving.

Most building enterprises of Lithuania are neither strong nor ready to effect the innovation activities. One way of the development of innovation activities at building enterprises is the creation of a network of specialized innovation spreading centres. Such centres would embrace the stages of creation of building innovations, their transfer, implementation at building enterprises. The coordination of innovation activities should be carried out by a specialized building innovation development institution.

A very prospective and important area of specialization of building innovation spreading centres is heat saving: the system of building innovation spreading centres should also include units involved in the comprehensive solving of heat saving problems.

The solution of heat saving problems is also related to the development of consultancy activities: the development of consultancy is the essential condition for promotion of innovation processes at Lithuanian building enterprises.

\section{References}

1. European Commision. Green Paper on Innovation. $1996.160 \mathrm{p}$.

2. McCarthy Sean. New Europe // Innovation \& Technology Transfer. 04/97, $15 \mathrm{p}$.

3. Б. Мельникас. Предпринимательство. Вильнюс: ЛИИ, $1992.320 \mathrm{c}$

4. J.A. Staškevičius. Inovatika ir inovacijos // Verslas, vadyba ir studijos'96: Respublikinès konferencijos medžiaga. Vilnius: Technika, 1997, p. 304-307.

5. E. Zavadskas, A. Kaklauskas, A. Banaitis, V. Jonaitis. Creation of rational entrepreneurship conditions in construction industry of Lithuania // Statyba, IV t., Nr. 1. Vilnius: Technika, 1998, p. 78-85.

Itteikta 19980721

\section{INOVACINĖS VEIKLOS STATYBOJE PLĖTOJIMAS TAUPANT ŠILUMOS IŠTEKIIUS}

\section{B. Melnikas, A. Jakubavičius, R. Strazdas}

Sa n trauka

Statyba yra viena svarbiausių ūkio šakų, daugiausia lemiančių šalies ekonominị, socialinị, technologini vystymą.

Statyboje sukurtų produktu kiekis, kokybè bei jų ekonominiai parametrai smarkiai veikia galimybes pasiekti tam tikrą socialinio gyvenimo kokybès bei materialinès gamybos ir paslaugu modernumo lygi: statybos produkcija reiškiasi kaip esminis veiksnys, darantis įtaką kaštų lygiui visose visuomenès ekonominio gyvenimo grandyse bei ribojantis ekonomines galimybes plètoti socialinę sferą bei materialinę veiklą daugelyje visuomenès raidos sričiu.

Statybos raida yra tiesiogiai sietina su galimybemis efektyviai naudoti ir taupyti šilumos išteklius: būtent statyboje kuriamy projektų parametrai daug lemia ekonominès veiklos efektyvumą energetinių, tarp jų šilumos išteklių naudojimo prasme. 
Ieškant büdų plètoti inovacinę veiklą statyboje, taip pat šilumos ištekliu taupymo srityje, būtina suformuoti specializuotą, inovacinę veiklą betarpiškai vykdančiu institucijų sistemą, orientuotą i darbą rinkos konkurencijos sąlygomis bei pajègią igyvendinti efektyvias šilumos naudojimo technologijas, kitas šilumos taupymo priemones. Suformavus tokia sistema reikia sukurti atitinkamus vadybinius organizacinius modelius bei įvertinti jų realizavimo galimybes.

Inovacinés veiklos aktyvinimas statyboje turètų pletotis šiomis kryptimis:

1. Inovatyvių veiklos valdymo metodụ kūrimas ir platus taikymas.

2. Atliekamų darbų ir teikiamų paslaugų kokybès kèlimas inovaciju pagrindu.

3. Darbo našumo didinimas inovaciju pagrindu.

4. Darbų savikainos mažinimas inovacijų pagrindu.

5. Personalo kvalifikacijos tobulinimas.

6. Informacijos paskleidimas (informacija apie naują technika, technologiją, medžiagas ir t.t.).

Dèl turimo potencialo nepakankamumo statybos versle vyraujančios smulkios ir vidutinès įmonès negali sẻkmingai ir efektyviai vykdyti inovacinę veiklą, sprendžiančią iškylančias problemas. Todèl tikslinga būtų statybos įmonèms deleguoti dali savo funkcijų bei potencialo, sietino su inovacinès veiklos plètojimu, kooperavimosi pagrindu steigiant ir palaikant regioninius statybos inovaciju plètros centrus. I kiekvieną tokio statybos inovacijų plètros centro veiklą turetų būti integruotas Lietuvos mokslinis ir finansinis potencialas bei gamybinis potencialas, veikiantis statybos sferoje.

Beje, tokių statybos inovaciju plètros centrų steigimas ir raida turetų būti orientuota ị sprendimą tų problemų, kurios yra sietinos su šilumos taupymu.

Apibendrinant atliktus tyrimus galima padaryti tokias išvadas:

- inovacines veiklos statybos sferoje plétojimas yra svarbi sąlyga tolesniam šalies ekonominiam, socialiniam, technologiniam vystymuisi, todèl inovacijų skatinimas yra laikytinas prioritetine statybos valdymo tobulinimo problema. Inovaciju skatinimas yra ypač reikšmingas šilumos taupymo požiūriu;

- dauguma Lietuvos statybos imoniu nèra pajègios ir nepasirengusios vykdyti inovacinę veiklą. Vienas iš inovacinès veiklos plètojimo statybos įmonése būdų yra specializuotu inovacijas skleidžiančiu centru tinklo kūrimas. Tokie centrai savo veikla turètų apimti statybos inovaciju kūrimo, perdavimo, diegimo statybos imonèse etapus. Inovacinę veiklą turètu koordinuoti specializuota statybos inovaciju plètros institucija;

- labai perspektyvi ir svarbi statybos inovacijas skleidžiančiu centrų specializacijos sritis - šilumos taupymas: inovaciju plètros centru tinklo sistemoje turètų bũti šilumos taupymo problemas kompleksiškai sprendžiančių padalinių;

- šilumos taupymo problemų sprendimas yra sietinas ir su konsultacinés veiklos plètojimu: konsultavimo pletojimas statyboje yra esminè sąlyga skatinti inovacijų procesus Lietuvos statybos įmonèse.

Borisas MELNIKAS. Doctor Habil, Professor. Department of Management. Vilnius Gediminas Technical University, Sauletekio al. 11, 2040 Vilnius. Doctor (social sciences, 1979), Dr Habil (social sciences, 1987), Professor (1990). Author of 30 books and brochures, 200 publications on management, economy and construction organisation.

Artüras JAKUBAVIČIUS. MSc (management). Vilnius Gediminas Technical University, Saulètekio al. 11, 2040 Vilnius. Author of 8 publications on management, economy and building organisation.

Rolandas STRAZDAS. MSc (management). Vilnius Gediminas Technical University, Sauletekio al. 11, 2040 Vilnius. Author of 7 publications on management, economy and building organisation. 